\title{
In-Silico Investigation on Chloroquine Derivatives: A Potential Anti-COVID-19 Main Protease
}

\author{
Dayo Felix Latona ${ }^{1}$ (D), Oluwatumininu Abosede Mutiu ${ }^{1}$ (D), Moriam Dasola Adeoye ${ }^{2 * * \text { D }}$, Abel Kolawole \\ Oyebamiji 3,*iD, Sunday Adewale Akintelu $^{4}$ (D), Adeyinka S. Adedapo ${ }^{5, *(D)}$ \\ 1 Department of Pure and Applied Chemistry, Osun State University, Osogbo, Nigeria; Dayo.latona@uniosun.edu.ng \\ (D.F.L.); \\ 2 Department of Chemical Sciences, Fountain University, Osogbo, Nigeria; dasoladeoye@yahoo.com (M.D.A.); \\ 3 Department of Basic Sciences, Adeleke University, PMB 250, Ede, Osun State, Nigeria. abeloyebamiji@gmail.com \\ (A.K.O.); \\ 4 School of Chemistry and Chemical Engineering, Beijing Institute of Technology, Beijing, China. \\ akintelusundayadewale@gmail.com (S.A.A.); \\ 5 Research Centre for Synthesis and Catalysis, Department of Chemical Sciences, University of Johannesburg, P.O Box 524, \\ Auckland Park, Johannesburg, 2006, Gauteng, South Africa.; aadeyinka@uj.ac.za (A.S.A.); \\ * Correspondence: aadeyinka@uj.ac.za (A.S.A.); abeloyebamiji@gmail.com (A.K.O.); dasoladeoye@yahoo.com (M.D.A.); \\ Scopus Author ID 57189714998
}

Received: 27.10.2021; Revised: 30.11.2021; Accepted: 2.12.2021; Published: 12.12.2021

Abstract: SARS-CoV-2 (Covid 19) continues to be a great threat to lives globally as it causes illnesses such as the common cold, severe acute respiratory syndrome and spreads easily among people. In this work, thirteen molecular compounds were studied via quantum chemical calculations, molecular docking, and dynamic simulation, and ADMET (absorption, distribution, metabolism, excretion, and toxicity). The obtained descriptors (Log P, HBA, HBD, and molecular weight) showed that the studied compounds have the ability to act as a drug. Thus, it was detected that all the studied selected compounds possess a better tendency to inhibit main coronavirus protease; however, compound $\mathrm{C}_{1}$ has a higher tendency to inhibit main coronavirus protease than the other compounds, including the standard (Chloroquine). ADMET properties of compound $\mathrm{C}_{1}$ proved that the predicted ADMET level was better than the ADMET properties of the referenced drug.

Keywords: chloroquine; COVID-19; SARS-CoV-2; molecular dynamic simulation; DFT; docking; ADMET.

(C) 2021 by the authors. This article is an open-access article distributed under the terms and conditions of the Creative Commons Attribution (CC BY) license (https://creativecommons.org/licenses/by/4.0/).

\section{Introduction}

The novel Severe Acute Respiratory Syndrome Coronavirus 2 (SARS-CoV-2) or COVID-19 is a highly contagious disease that causes respirational, gastrointestinal, and neurological diseases. The virus first appeared in December 2019, when a number of patients with pneumonia of unknown cause were noticed in Wuhan, China [1].

Due to the absence of any known cure and because of the situation of a "public health emergency", many drugs have been tried lately in the treatment for COVID-19 that includes low-cost antimalarial drug chloroquine and its derivative hydroxychloroquine (HCQ), along with many other antiviral drugs such as Remdesivir, Ivermectin, and Nitazoxanide among others [2].

Chloroquine has a quinoline ring like quinine and a side chain identical to quinacrine; the chloride atom in the seventh position appears to be crucial to its antimalarial activity [3]. 
Since then, CQ and HCQ have been tested against Zika, Ebola, human immunodeficiency virus, hepatitis $\mathrm{C}$ virus, coronaviruses, and others [4], exhibiting broad-spectrum antiviral properties.

Presently there is no known specific, effective, proven pharmacological treatment for SARS-CoV-2. In-vitro studies have suggested that chloroquine, an immunomodulant drug traditionally used to treat malaria, effectively reduces viral replication in other infections, including the SARS-associated coronavirus (CoV) MERS-CoV [5,6].

In this work, fourteen molecular compounds were studied to identify the descriptors that predict the anti-SARS-CoV-2 activities of chloroquine derivatives using DFT and to study the physicochemical properties and pharmacokinetic properties using ADMETSAR and observe the molecular interactions between derivatives of chloroquine and COVID-19 main protease (PDB code: 6w63) [7] using in silico approaches.

\section{Materials and Methods}

\subsection{Optimization.}

Thirteen derivatives of Chloroquine including Chloroquine were optimized via in silico method using Spartan 14 software [8]. The molecular descriptors which includes molecular weight, hydrophobicity (Log P), volume (V), Area, polar surface area (PSA), ovality, dipole moment (DM), Hydrogen bond donor(HBA),Hydrogen bond acceptor (HBA) Highest occupied molecular Orbital ( Е $_{\text {HOмо }}$ ), Lowest unoccupied molecular orbital (ELUM) and Band gap ( $\left.\mathrm{E}_{\mathrm{HOMO}}-\mathrm{E}_{\mathrm{LUMO}}\right)$ energies were studied to predict the antiviral activities of the compounds on Covid-19. The name of the studied compounds were ((4-)(7-chloroquinolin-4yl)amino)pentyl)(ethyl)amino)methanol $\quad\left(C_{1}\right), \quad$ N4-(7-chloroquinolin-4-yl)-N1-ethyl-N1-(4fluorobenzyl)pentane-1,4-diamine $\quad\left(\mathrm{C}_{2}\right), \quad \mathrm{N} 4-(7-c h l o r o q u i n o l i n-4-y l)-N 1-e t h y l-N 1-$ (fluoromethyl)pentane-1,4-diamine $\quad\left(\mathrm{C}_{3}\right), \quad$ N4-(7-chloroquinolin-4-yl)-N1-ethyl-N1-(2,2,2trifluoroethyl)pentane-1,4-diamine $\quad\left(\mathrm{C}_{4}\right), \quad \mathrm{N} 4-(7-c h l o r o q u i n o l i n-4-y l)-N 1-m e t h y l-N 1-$ ((trifluoromethoxy)methyl)pentane-1,4-diamine $\left(\mathrm{C}_{5}\right)$, N4-(7-chloroquinolin-4-yl)-N1-methylN1-(phenoxymethyl)pentane-1,4-diamine $\left(\mathrm{C}_{6}\right), \quad$ N4-(7-chloroquinolin-4-yl)-N1-ethyl-N1methylpentane-1,4-diamine $\quad\left(\mathrm{C}_{7}\right), \quad \mathrm{N} 4-(7-c h l o r o q u i n o l i n-4-y 1)-N 1-(m e t h o x y m e t h y l)-N 1-$ methylpentane-1,4-diamine $\left(\mathrm{C}_{8}\right)$, N4-(7-chloroquinolin-4-yl)-N1-methyl-N1-propylpentane1,4-diamine $\quad\left(\mathrm{C}_{9}\right), \quad 2-((4-((7-$ chloroquinolin-4-yl)amino)pentyl)(methyl)amino)acetonitrile $\left(\mathrm{C}_{10}\right)$, N1-butyl-N4-(7-chloroquinolin-4-yl)-N1-methylpentane-1,4-diamine $\left(\mathrm{C}_{11}\right), \quad \mathrm{N} 4-(7-$ chloroquinolin-4-yl)-N1-(furan-2-ylmethyl)-N1-methylpentane-1,4-diamine $\quad\left(\mathrm{C}_{12}\right), \quad \mathrm{N} 4-(7-$ chloroquinolin-4-yl)-N1-methyl-N1-(thiophen-2-ylmethyl)pentane-1,4-diamine $\quad\left(\mathrm{C}_{13}\right), \quad \mathrm{N} 1-$ ((1H-pyrrol-2-yl)methyl)-N4-(7-chloroquinolin-4-yl)-N1-methylpentane-1,4-diamine $\quad\left(\mathrm{C}_{14}\right)$ (Table 1).

\subsection{Docking study.}

The docking study was executed by preparing the receptor (COVID-19 main protease with PDB code: 6w63) obtained from the protein data bank (www.rcsb.org) and chloroquine derivatives. Series of software were involved in accomplishing molecular docking to determine the ligand's affinity towards the target and to view the non-bonding interaction between the studied complexes. The software used were PyMOL, Autodock tool 1.5.6, autodock vina, and 
Discovery studio. The observed grid box was: center $(X=-26.479, Y=12.595, Z=58.704)$ and size $(X=54, Y=68, Z=72)$; and the spacing was set at $1.00 \AA$.

\subsection{ADMET properties.}

ADMETSAR1, as an online ADMET software, was used to achieve absorption, distribution, metabolism, excretion, and toxicity (ADMET) of the studied compounds as well as the referenced drug (Chloroquine) [9]. Twenty-three factors were observed, and this includes Blood-Brain Barrier, Human Intestinal Absorption, Caco-2 Permeability, P-glycoprotein Substrate, P-glycoprotein Inhibitor, Renal Organic Cation Transporter, Subcellular localization, CYP450 2C9 Substrate, CYP Inhibitory Promiscuity, AMES Toxicity, Carcinogens, and Biodegradation.

Table 1. The schematic structures of the studied molecules.

\begin{tabular}{|c|c|c|}
\hline & $\mathbf{R}_{1}$ & $\mathbf{R}_{\mathbf{2}}$ \\
\hline $\mathrm{C}_{1}$ & $\mathrm{OH}$ & $\mathrm{CH}_{3}$ \\
\hline $\mathrm{C}_{2}$ & & $\mathrm{CH}_{3}$ \\
\hline $\mathrm{C}_{3}$ & $\mathrm{~F}$ & $\mathrm{CH}_{3}$ \\
\hline $\mathrm{C}_{4}$ & $\mathrm{CF}_{3}$ & $\mathrm{CH}_{3}$ \\
\hline $\mathrm{C}_{5}$ & $\mathrm{OCF}_{3}$ & $\mathrm{H}$ \\
\hline $\mathrm{C}_{6}$ & $\mathrm{OC}_{6} \mathrm{H}_{5}$ & $\mathrm{H}$ \\
\hline $\mathrm{C}_{7}$ & $\mathrm{CH}_{3}$ & $\mathrm{H}$ \\
\hline $\mathrm{C}_{8}$ & $\mathrm{OCH}_{3}$ & $\mathrm{H}$ \\
\hline $\mathrm{C}_{9}$ & $\mathrm{OC}_{2} \mathrm{H}_{5}$ & $\mathrm{H}$ \\
\hline $\mathrm{C}_{10}$ & $\mathrm{CN}$ & $\mathrm{H}$ \\
\hline $\mathrm{C}_{11}$ & $\mathrm{C}_{3} \mathrm{H}_{7}$ & $\mathrm{H}$ \\
\hline $\mathrm{C}_{12}$ & & $\mathrm{H}$ \\
\hline $\mathrm{C}_{13}$ & & $\mathrm{H}$ \\
\hline $\mathrm{C}_{14}$ & & $\mathrm{H}$ \\
\hline
\end{tabular}

\section{Results and Discussion}

\subsection{Calculated molecular properties from studied compounds.}

Series of descriptors that describe potential anti- COVID-19 main protease activities of the studied derivatives of chloroquine were molecular weight (MW), hydrophobicity $(\log \mathrm{P})$, 
Hydrogen bond donor (HBA), Hydrogen bond acceptor (HBA), highest occupied molecular orbital energy ( $\left.\mathrm{E}_{\mathrm{HOMO}}\right)$, lowest unoccupied molecular orbital ( $\left.\mathrm{E}_{\mathrm{LUMO}}\right)$ and Bandgap ( $\mathrm{E}_{\mathrm{HOMO}}-$ $E_{\text {Lumo }}$ ) energies as presented in Table 2. The ability of the studied compounds to act as the drug-like compound was examined by considering the Lipinski rule of five ( $\mathrm{MW} \leq 500 \mathrm{amu}$, $\log \mathrm{P} \leq 5, \mathrm{HBD} \leq 5, \mathrm{HBA} \leq 10)$, and it was observed that the calculated molecular weight, lipophilicity (Log P) hydrogen bond donor (HBD) and hydrogen bond acceptor (HBA) values were within the acceptable range; thus, the studied derivatives of chloroquine possess the ability to act as a drug. Other calculated descriptors were reported in Table 2.

Table 2. Calculated molecular descriptors for the studied compounds.

\begin{tabular}{l|c|c|c|c|c|c|c} 
& $\begin{array}{c}\text { HOMO } \\
(\mathbf{e V})\end{array}$ & $\begin{array}{c}\text { LUMO } \\
(\mathbf{e V})\end{array}$ & $\mathbf{B G}$ & HBA & HBD & MW (amu) & Log p \\
\hline $\mathrm{C}_{1}$ & -5.47 & -1.25 & 4.22 & 3 & 1 & 413.968 & 2.49 \\
\hline $\mathrm{C}_{2}$ & -4.29 & -1.72 & 2.57 & 3 & 1 & 337.87 & 0.51 \\
\hline $\mathrm{C}_{3}$ & -5.65 & -1.25 & 4.4 & 3 & 1 & 387.877 & 1.57 \\
\hline $\mathrm{C}_{4}$ & -5.65 & -1.25 & 4.4 & 4 & 1 & 403.876 & 0.00 \\
\hline $\mathrm{C}_{5}$ & -5.46 & -1.26 & 4.2 & 4 & 1 & 411.977 & 1.98 \\
\hline $\mathrm{C}_{6}$ & -5.51 & -1.25 & 4.26 & 3 & 1 & 333.907 & 1.14 \\
\hline $\mathrm{C}_{7}$ & -5.47 & -1.26 & 4.21 & 4 & 1 & 349.906 & 0.16 \\
\hline $\mathrm{C}_{8}$ & -5.47 & -1.25 & 4.22 & 3 & 1 & 361.961 & 1.89 \\
\hline $\mathrm{C}_{9}$ & -5.69 & -1.26 & 4.41 & 4 & 1 & 344.89 & 0.69 \\
\hline $\mathrm{C}_{10}$ & -5.50 & -1.25 & 4.25 & 3 & 1 & 347.934 & 1.56 \\
\hline $\mathrm{C}_{11}$ & -5.41 & -1.42 & 3.99 & 4 & 1 & 385.939 & 0.3 \\
\hline $\mathrm{C}_{12}$ & -5.59 & -1.24 & 4.35 & 4 & 1 & 402.006 & 1.02 \\
\hline $\mathrm{C}_{13}$ & -5.41 & -1.24 & 4.17 & 4 & 2 & 384.955 & 0.08 \\
\hline $\mathrm{C}_{14}$ & -5.50 & -1.25 & 4.25 & 4 & 2 & 335.879 & -0.2
\end{tabular}

\subsection{Docking studies on chloroquine derivatives and COVID-19 main protease.}

The studied compounds were docked against COVID-19 main protease (PDB code: 6w63) to examine the binding affinity and non-bonding interaction present in the studied complexes. The calculated binding affinity for the studied complexes were $-6.66 \mathrm{kcal} / \mathrm{mol}$ for $\mathrm{C}_{1},-5.8 \mathrm{kcal} / \mathrm{mol}$ for $\mathrm{C}_{2},-6.2 \mathrm{kcal} / \mathrm{mol}$ for $\mathrm{C}_{3},-6.4 \mathrm{kcal} / \mathrm{mol}$ for $\mathrm{C}_{4},-6.0 \mathrm{kcal} / \mathrm{mol}$ for $\mathrm{C}_{5},-5.9$ $\mathrm{kcal} / \mathrm{mol}$ for $\mathrm{C}_{6},-6.1 \mathrm{kcal} / \mathrm{mol}$ for $\mathrm{C}_{7},-6.1 \mathrm{kcal} / \mathrm{mol}$ for $\mathrm{C}_{8},-6.0 \mathrm{kcal} / \mathrm{mol}$ for $\mathrm{C}_{9},-5.8 \mathrm{kcal} / \mathrm{mol}$ for $\mathrm{C}_{10},-6.3 \mathrm{kcal} / \mathrm{mol}$ for $\mathrm{C}_{11},-6.1 \mathrm{kcal} / \mathrm{mol}$ for $\mathrm{C}_{12}$, and $-6.3 \mathrm{kcal} / \mathrm{mol}$ for $\mathrm{C}_{13}$. The docked compounds have nine (9) conformations each, and the conformation with the lowest binding affinity value is considered to be the best [10-25]; therefore, compound $\mathrm{C}_{1}$ with $-6.66 \mathrm{kcal} / \mathrm{mol}$ is considered to have the best ability to inhibit COVID-19 main protease than other studied compounds and the referenced drug. This revealed that the derivative $\left(\mathrm{R}_{1}=\mathrm{OH}\right.$ and $\left.\mathrm{R}_{2}=\mathrm{CH}_{3}\right)$ attached to the studied parent compound enhanced the biological activity of the studied parent compound than other studied derivatives.

The residue involved in each interaction were Cys 44, MET 49, MET 165, CYS 145, HIS 163 for $\mathrm{C}_{1}$; MET 49, HIS 41, HIS 164, CYS 44, CYS 145, MET 165, GLN 189, ARG 188 for $\mathrm{C}_{2}$; CYS 44, CYS 145, MET 49, HIS 41, GLU 145 for $\mathrm{C}_{3}$; GLU A:166, ARG A:188, THR

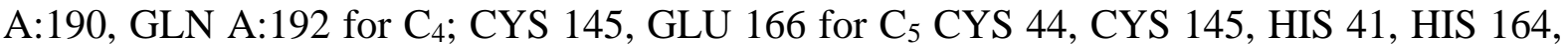
MET 165, MET 49, PRO 52 for $\mathrm{C}_{6}$; MET 49, CYS 44, HIS 41, MET 165, HIS 164, GLU 166, GLN 192 for C $_{7}$, CYS 145, HIS 41, CYS 44, MET 49, PRO 168, GLU 166, LEU 167 for $\mathrm{C}_{8}$ CYS 44, PRO 52, CYS 145, MET 49, HIS 41, MET 165, HIS 164, GLN 189 for C9; CYS 44, MET 165, HIS 41, HIS 164, PRO 168, LEU 167, CYS 145 for C $_{10}$; CYS 145, MET 165, HIS 41 for $\mathrm{C}_{11}$; CYS 44, PRO 52, HIS 41, MET 49, HIS 164, CYS 145, MET 165 for $\mathrm{C}_{12}$; CYS 44, MET 165, PRO 168, HIS 41, CYS 145 for $\mathrm{C}_{13}$ (Table 3) ( Figure 1). 
Table 3. Binding affinity and interactions among residues of drugs and COVID-19 main protease.

\begin{tabular}{|c|c|c|}
\hline S. No & Binding affinity $\mathrm{kcal} / \mathrm{mol}$ & Amino acid residue \\
\hline $\mathrm{C}_{1}$ & -6.6 & CYS A:44, MET A:49, MET A:165, CYS A:145, HIS A:163 \\
\hline $\mathrm{C}_{2}$ & -5.8 & $\begin{array}{c}\text { MET A:49, HIS A:41, HIS A:164, CYS A:44, CYS A:145, MET } \\
\text { A:165, GLN A:189, ARG A:188 }\end{array}$ \\
\hline $\mathrm{C}_{3}$ & -6.2 & CYS A:44, CYS A:145, MET A:49, HIS A:41 GLU A:145 \\
\hline $\mathrm{C}_{4}$ & -6.4 & GLU A:166, ARG A:188, THR A:190, GLN A:192 \\
\hline $\mathrm{C}_{5}$ & -6.0 & CYS A:145, GLU A:166 \\
\hline $\mathrm{C}_{6}$ & -5.9 & $\begin{array}{c}\text { CYS A:44, CYS A:145, HIS A:41, HIS A:164, MET A :165, } \\
\text { MET A:49, PRO A:52 }\end{array}$ \\
\hline $\mathrm{C}_{7}$ & -6.1 & $\begin{array}{l}\text { MET A:49, CYS A:44, HIS A:41, MET A :165, HIS A :164, } \\
\text { GLU A:166, GLN A:192 }\end{array}$ \\
\hline $\mathrm{C}_{8}$ & -6.1 & $\begin{array}{c}\text { CYS A :145, HIS A:41, CYS A:44, MET A:49, PRO A:168, } \\
\text { GLU A:166, LEU A:167 }\end{array}$ \\
\hline $\mathrm{C}_{9}$ & -6.0 & $\begin{array}{c}\text { CYS A:44,PRO A:52, CYS A:145, MET A:49, HIS A:41, MET } \\
\text { A:165, HIS A:164, GLN A:189 }\end{array}$ \\
\hline $\mathrm{C}_{10}$ & -5.8 & $\begin{array}{c}\text { CYS A:44, MET A:165,HIS A:41, HIS A:164, PRO A:168, LEU } \\
\text { A:167,CYS A:145 }\end{array}$ \\
\hline $\mathrm{C}_{11}$ & -6.3 & CYS A:145, MET A:165, HIS A :41 \\
\hline $\mathrm{C}_{12}$ & -6.1 & $\begin{array}{c}\text { CYS A:44, PRO A:52, HIS A:41, MET A:49, HIS A:164, CYS } \\
\text { A:145, MET A:165 }\end{array}$ \\
\hline $\mathrm{C}_{13}$ & -6.3 & CYS A:44, MET A:165, PRO A:168, HIS A:41, CYS A145 \\
\hline Chloroquie & -6.1 & $\begin{array}{r}\text { HIS A:41, CYS A:145, MET A:49, CYS A:44, ARG A:188, THR } \\
\text { A:190, GLN A:192, GLU A:166 }\end{array}$ \\
\hline
\end{tabular}

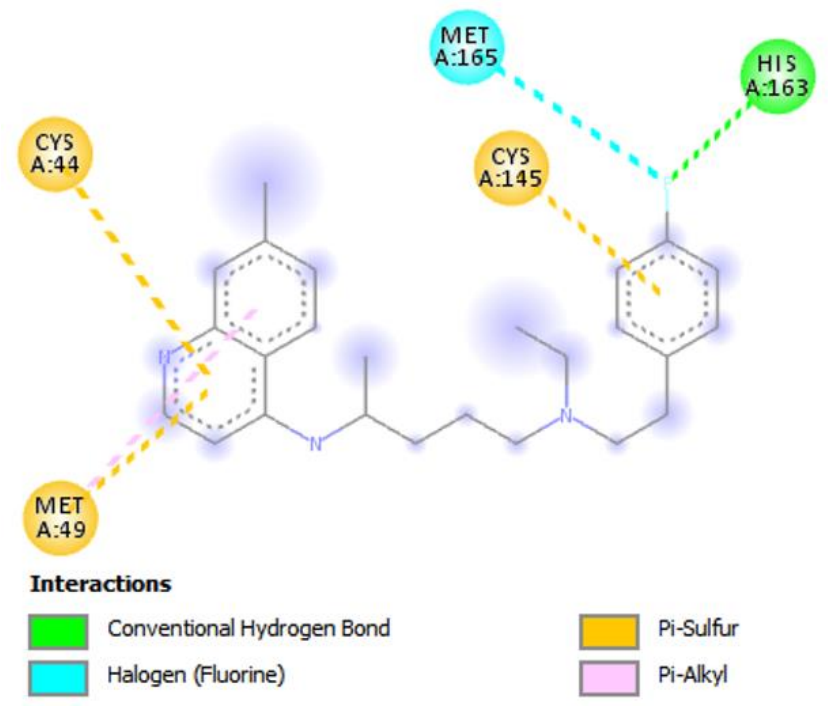

Figure 1. 2D structures of COVID-19 main protease (PDB code: $6 w 63$ ) and compound $\mathrm{C}_{1}$.

\subsection{Molecular dynamics simulation study.}

\subsubsection{Root mean square deviation analysis.}

The values of the calculated root mean square deviation (RMSD) of the backbone atoms of the studied receptor were used to determine the degree of deviation from the initial structure when binding and the stability of the complexes during the 50,000ps (50 ns) MD simulation time. The RMSD of the studied complex shows a stable conformation, particularly in the last $10 \mathrm{~ns}$ of the simulation, which indicated stable conformation for the studied systems, as shown in Figure 2. The calculated average RMSD values are $0.15 \mathrm{~A}^{\circ}$ for $\mathrm{C}_{1}$ and 0.25 for Chloroquine.

\subsubsection{Root of mean square fluctuation.}

The studied root means square fluctuation (RMSF) helps determine the flexibility of residues upon binding of the two compounds tested during (50 ns) simulation time, as shown in Figure 3. It is noticeable that there is a similarity in the trend at which the observed residue 
oscillated; though, little variation was detected between the two compounds. As shown in Figure 3, it was established that compound $\mathrm{C}_{1}$ displayed a minor degree of deviation, and this demonstrates a higher level of affinity for it to inhibit main coronavirus protease than chloroquine.

\subsubsection{Binding free energy.}

As revealed in Table 4 below, the calculated binding energy proved that compound $\mathrm{C}_{1}$ possesses a better ability to inhibit COVID-19 main protease (PDB code: 6w63) than the standard. The calculated free energy for $C_{1}$ includes van der Waal energy $(-190.113 \mathrm{~kJ} / \mathrm{mol})$, electrostatic energy $(-13.126 \mathrm{~kJ} / \mathrm{mol})$, polar solvation energy $(105.195 \mathrm{~kJ} / \mathrm{mol})$ and $(-20.887$ $\mathrm{kJ} / \mathrm{mol}$ ) while the values for Chloroquine are $-171.754 \mathrm{~kJ} / \mathrm{mol},-6.654 \mathrm{~kJ} / \mathrm{mol}, 64.576 \mathrm{~kJ} / \mathrm{mol}$ and $-18.386 \mathrm{~kJ} / \mathrm{mol}$ respectively. This shows that van der Waal energy, polar solvation energy, electrostatic solvation energy, and SASA energy favored the binding of compound $\mathrm{C}_{1}$ to main coronavirus protease.

\subsubsection{Solvent Accessible Surface Area (SASA).}

Solvent accessible surface area (SASA) analysis was used to determine the interaction between complexes and solvents [26]. In Figure 4, it was observed that the SASA values for the protein-ligand complexes during MD were relatively stable; this showed that there were no significant changes in the protein structure. Also, compound $\mathrm{C}_{1}$ has a higher SASA value, which means $\mathrm{C}_{1}$ should interact more and be accessible for solvents (Figure 4).

\subsubsection{Radius of Gyration (Rg) in MD simulation.}

The radius of gyration $(\mathrm{Rg})$ was used to discover the compactness changes of the ligand-protein complex during the 50,000ps (50 ns) MD simulation time. No significant changes were observed for $\mathrm{C}_{1}$ and Chloroquine, which implied great stability and compactness of the complexes. Although, a little deviation was noticed for chloroquine around 15000ps and 25000ps, which suggested a loss of compactness for its complex (Figure 5).

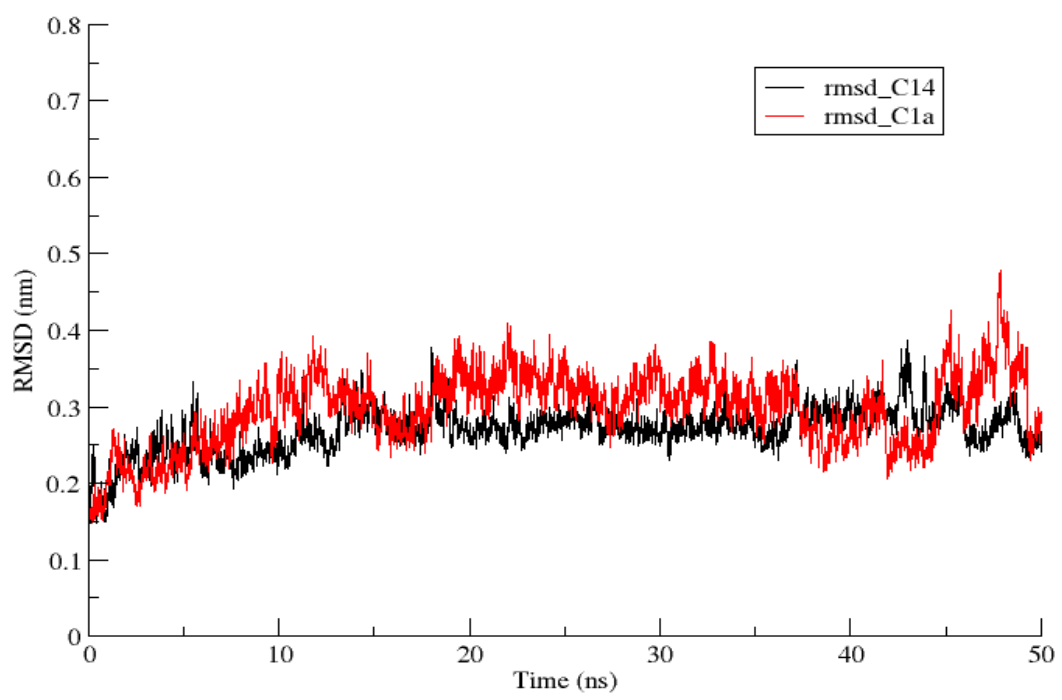

Figure 2. Root mean square deviation of the studied complexes. 


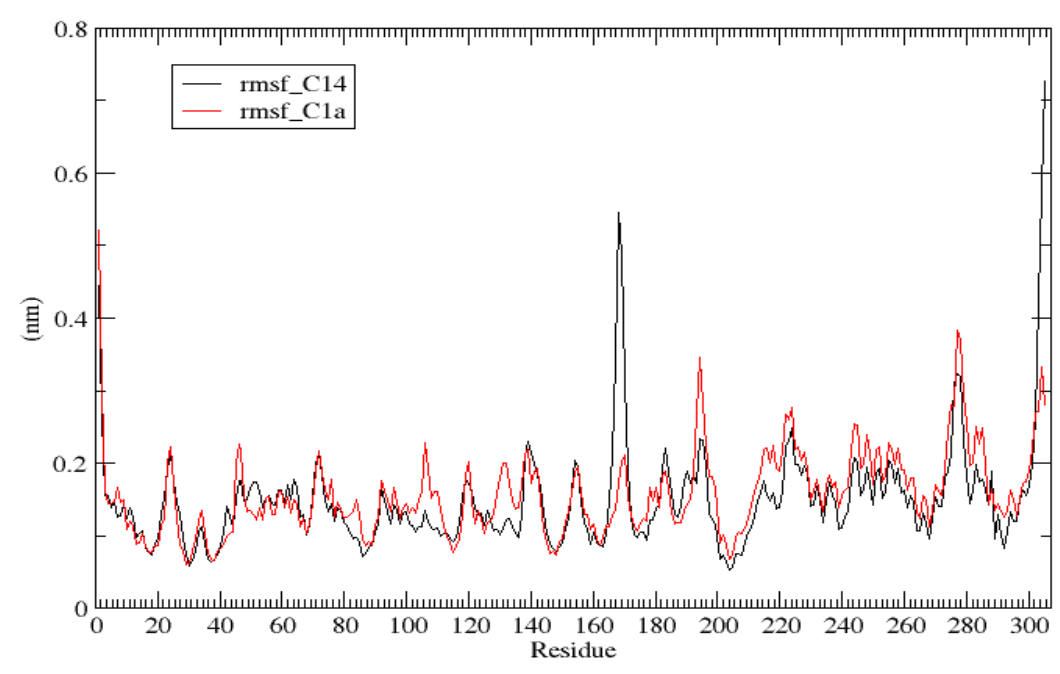

Figure 3. Root mean square fluctuation of the studied complexes.

Table 4. Calculated binding free energies for compound $\mathrm{C}_{1}$ and reference drug.

\begin{tabular}{l|c|c|c|c|c} 
& $\begin{array}{c}\text { Van der Waal } \\
\text { energy }(\mathbf{k J} / \mathbf{m o l})\end{array}$ & $\begin{array}{c}\text { Electrostatic energy } \\
(\mathbf{k J} / \mathbf{m o l})\end{array}$ & $\begin{array}{c}\text { Polar solvation } \\
\text { energy }(\mathbf{k J} / \mathbf{m o l})\end{array}$ & $\begin{array}{c}\text { SASA energy } \\
(\mathbf{k J} / \mathbf{m o l})\end{array}$ & $\begin{array}{c}\text { Binding energy } \\
(\mathbf{k J} / \mathbf{m o l})\end{array}$ \\
\hline $\mathbf{R d}$ & $-171.754 \pm 0.698$ & $-6.654 \pm 0.204$ & $64.576 \pm 0.422$ & $-18.386 \pm 0.059$ & $-132.202 \pm 0.712$ \\
\hline $\mathbf{C 1}$ & $-190.113 \pm 0.622$ & $-13.126 \pm 0.423$ & $105.195 \pm 0.806$ & $-20.887 \pm 0.068$ & $-118.924 \pm 0.693$
\end{tabular}

Note: Rd: Reference drug; C1: ((4-((7-chloroquinolin-4-yl)amino)pentyl)(ethyl)amino)methanol

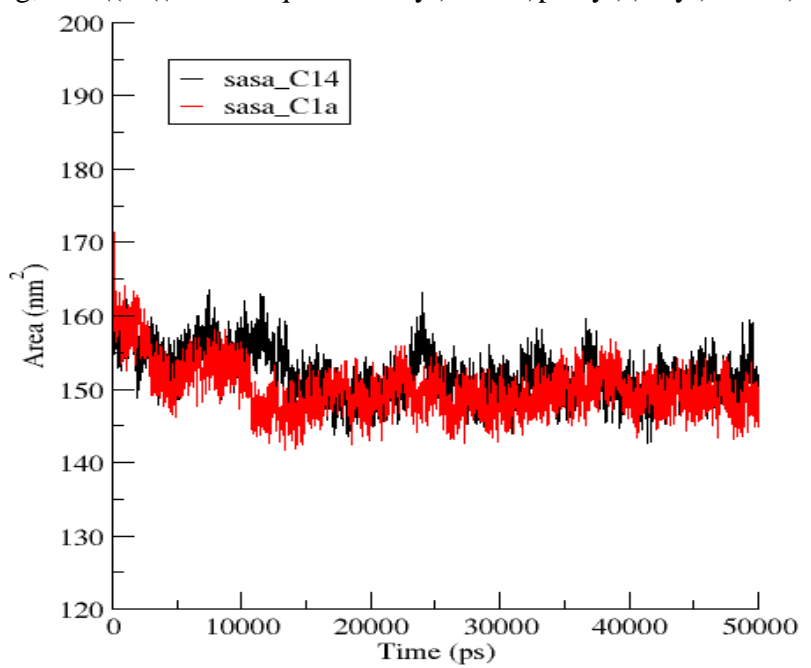

Figure 4. Solvent accessible surface area of the studied complexes.

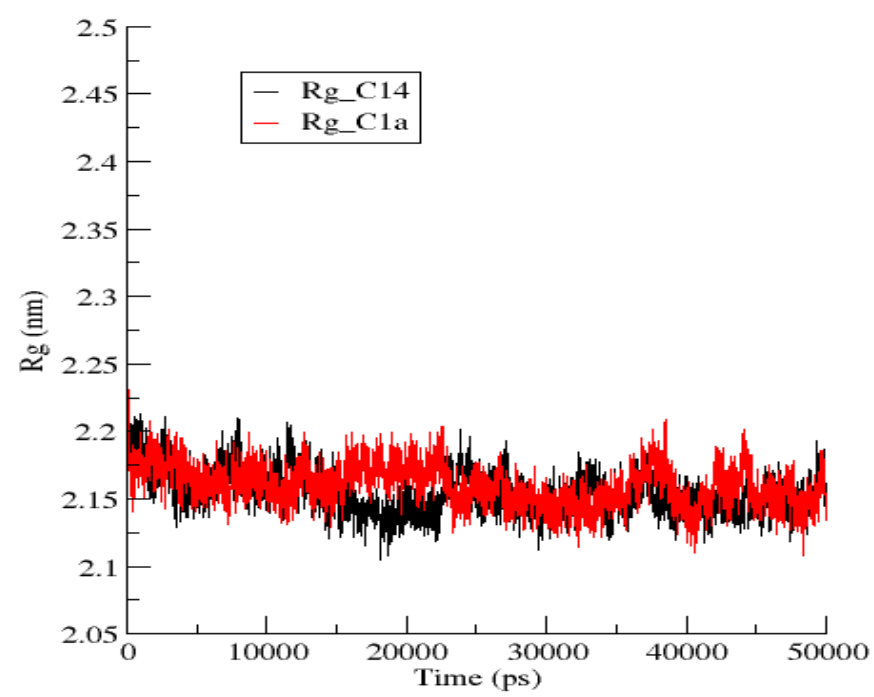

Figure 5. Radius of gyration of the studied complexes. 
3.4. ADMET properties of studied selected compounds.

The selected compounds were subjected to an ADMET study using the admetSAR server to predict the pharmacokinetic properties. A higher value of HIA denotes that the compound could be better absorbed from the intestinal tract upon oral administration [27]; thus, it was observed that the calculated human intestinal absorption (HIA) value for compound $\mathrm{C}_{1}$ was closer to the calculated value for Chloroquine (Standard). More so, the calculated bloodbrain barrier (BBB) value, which reveals the penetration level of drug-like compound, showed that the value calculated for compound $\mathrm{C} 1$ was higher than that of the reference drug, which revealed its efficiency level. Other considered ADMET factors were within the same range as the studied referenced drug [28] (Table 5).

Table 5. Predicted ADMET properties of compound $\mathrm{C}_{1}$ and Chloroquine.

\begin{tabular}{|c|c|c|c|c|}
\hline \multirow[b]{2}{*}{ Mode } & \multicolumn{2}{|c|}{ Compound $\mathrm{C}_{1}$} & \multicolumn{2}{|c|}{ Chloroquine } \\
\hline & Result & Probability & Result & Probability \\
\hline Blood-Brain Barrier & $\mathrm{BBB}+$ & 0.8121 & $\mathrm{BBB}+$ & 0.5355 \\
\hline Human Intestinal Absorption & $\mathrm{HIA}+$ & 0.9974 & HIA+ & 0.9881 \\
\hline Caco-2 Permeability & Caco2+ & 0.5717 & Caco2- & 0.5199 \\
\hline P-glycoprotein Substrate & Substrate & 0.8065 & Substrate & 0.8303 \\
\hline \multirow{2}{*}{ P-glycoprotein Inhibitor } & Inhibitor & 0.6577 & Non-inhibitor & 0.6523 \\
\hline & Inhibitor & 0.6432 & Inhibitor & 0.6471 \\
\hline Renal Organic Cation Transporter & Inhibitor & 0.6278 & Non-inhibitor & 0.6248 \\
\hline Subcellular localization & Lysosome & 0.9085 & Lysosome & 0.7498 \\
\hline CYP450 2C9 Substrate & Non-substrate & 0.8525 & Non-substrate & 0.8141 \\
\hline CYP450 2D6 Substrate & Substrate & 0.7969 & Non-substrate & 0.8754 \\
\hline CYP450 3A4 Substrate & Substrate & 0.552 & Non-substrate & 0.5000 \\
\hline CYP450 1A2 Inhibitor & Non-inhibitor & 0.7441 & Non-inhibitor & 0.6459 \\
\hline CYP450 2C9 Inhibitor & Non-inhibitor & 0.8682 & Non-inhibitor & 0.8562 \\
\hline CYP450 2D6 Inhibitor & Non-inhibitor & 0.8664 & Non-inhibitor & 0.6726 \\
\hline CYP450 2C19 Inhibitor & Non-inhibitor & 0.8331 & Non-inhibitor & 0.8903 \\
\hline CYP450 3A4 Inhibitor & Non-inhibitor & 0.7046 & Non-inhibitor & 0.7419 \\
\hline CYP Inhibitory Promiscuity & $\begin{array}{l}\text { High CYP Inhibitory } \\
\text { Promiscuity }\end{array}$ & 0.5 & $\begin{array}{l}\text { Low CYP Inhibitory } \\
\text { Promiscuity }\end{array}$ & 0.7470 \\
\hline \multirow{2}{*}{$\begin{array}{l}\text { Human Ether-a-go-go-Related Gene } \\
\text { Inhibition }\end{array}$} & Weak inhibitor & 0.7287 & Weak inhibitor & 0.6601 \\
\hline & Inhibitor & 0.8433 & Inhibitor & 0.7440 \\
\hline AMES Toxicity & AMES toxic & 0.8733 & AMES toxic & 0.6936 \\
\hline Carcinogens & Non-carcinogens & 0.8529 & Non-carcinogens & 0.8100 \\
\hline Fish Toxicity & High FHMT & 0.9895 & High FHMT & 0.9494 \\
\hline Tetrahymena Pyriformis Toxicity & High TPT & 0.9981 & High TPT & 0.9940 \\
\hline Honey Bee Toxicity & Low HBT & 0.8748 & Low HBT & 0.8661 \\
\hline Biodegradation & $\begin{array}{l}\text { Not ready } \\
\text { biodegradable }\end{array}$ & 1.0000 & $\begin{array}{l}\text { Not ready } \\
\text { biodegradable }\end{array}$ & 1.0000 \\
\hline
\end{tabular}

\section{Conclusions}

In this work, thirteen chloroquine derivatives were examined using the density functional theory method for optimization, docking, and molecular dynamics simulation studies to detect the biological interaction between the selected compounds and coronavirus main protease. It was observed that the studied compounds proved to be active potentials, antiCOVID-19 main protease agents. Also, compound $\mathrm{C}_{1}$ possesses better potentials to inhibit COVID-19 main protease than other studied compounds and the standard. Moreover, the calculated actual binding energy for compound $\mathrm{C}_{1}$ using molecular dynamic simulation methods further confirmed its ability to inhibit main coronavirus protease than other studied compounds, including the standard (Chloroquine). 


\section{Funding}

This research did not receive any specific grant from funding agencies in the public, commercial, or not-for-profit sectors.

\section{Acknowledgments}

We are grateful to the Department of Pure and Applied Chemistry, Osun State University, for the computational resources and Mrs. E.T. Oyebamiji and Miss Priscilla F. Oyebamiji for their assistance in the course of this study.

\section{Conflicts of Interest}

The authors declare no conflict of interest.

\section{References}

1. Wiersinga, W.J.; Rhodes, A.; Cheng, A.C.; Peacock, S.J.; Prescott, H.C. Pathophysiology, Transmission, Diagnosis, and Treatment of Coronavirus Disease 2019 (COVID-19): A Review. Jama 2020, 324, 782-793, https://doi.org/10.1001/jama.2020.12839.

2. Singh, A.K.; Akriti, S.; Altamash, S.; Ritu, S.; Anoop, M. Chloroquine and hydroxychloroquine in the treatment of COVID-19 with or without diabetes: A systematic search and a narrative review with a special reference to India and other developing countries. Diabetes \& Metabolic Syndrome: Clinical Research \& Reviews 2020, 14, 241-246, https://doi.org/10.1016/j.dsx.2020.03.011.

3. Nisha, C.; Ashwini, K.; Prateek, N.; Nityasha, G.; Pandey, A.V.; Bisht, H.; Babbarwal, V.K.; Srivastava, J.; Pandey, K.C.; Chauhan, V.S. Mechanism of malarial haem detoxification inhibition by chloroquine. Biochem J 2001, 355, 333-8, https://dx.doi.org/10.1042\%2F0264-6021\%3A3550333.

4. Vincent, M.J.; Bergeron, E.; Benjannet, S. Chloroquine is a potent inhibitor of SARS coronavirus infection and spread. Virol J. 2005, 2, https://doi.org/10.1186/1743-422X-2-69.

5. Savarino, A.; Boelaert, J.R.; Cassone, A.; Majori, G.; Cauda, R. Effects of chloroquine on viral infections: an old drug against today's diseases? Lancet Infect Dis. 2003, 3, 722-7, https://doi.org/10.1016/s14733099(03)00806-5.

6. Colson, P.; Rolain, J.-M.; Raoult, D. Chloroquine for the 2019 novel coronavirus SARS-CoV-2. International

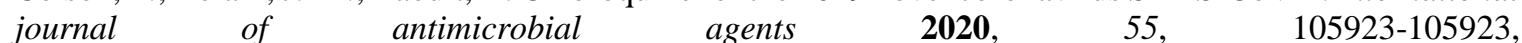
https://doi.org/10.1016/j.ijantimicag.2020.105923.

7. Semire, B.; Oyebamiji, A.K.; and Odunola, O. A. Tailoring of Energy Levels in (2Z)-2-cyano-2-[2-[(E)-2[2-[(E)-2-(p-tolyl)vinyl]thieno[3,2-b]thiophen-5-yl]vinyl]pyran-4-ylidene]acetic acid Derivatives via Conjugate Bridge and Fluorination of Acceptor units for Effective D- $\pi$-A Dye-Sensitized Solar Cells: DFTTDDFT Approach, Research on Chemical Intermediates 2017, 43, 18631879,https://doi.org/10.1007/s11164-016-2735-0.

8. Harsha, P. In Silico drug designing and docking analysis for hypertension using Nifedipine as lead molecule. International Journal of Pharmaceutical Research \& Development 2011, 3, 104-108.

9. Desai, B.; Sureja, D.; Naliapara, Y.; Shah, A.; Saxena, A.K. Synthesis and QSAR studies of 4-substituted phenyl-2,6-dimethyl-3, 5-bis-N-(substituted phenyl)carbamoyl-1,4-dihydropyridines as potential antitubercular agents. Bioorg Med Chem 2001, 9, 1993-1998, https://doi.org/10.1016/s0968-0896(01)001419.

10. Shen, J.; Cheng, F.; Xu, Y.; Li, W.; Tang, Y. Estimation of ADME Properties with Substructure Pattern Recognition. Journal of Chemical Information and Modeling 2010, 50, 1034-1041, https://doi.org/10.1021/ci100104j.

11. Oyebamiji, A.K.; Tolufashe, G.F.; Oyawoye, O.M.; Oyedepo, T.A.; Semire B. Biological Activity of Selected Compounds from Annona muricata Seed as Antibreast Cancer Agents: Theoretical Study. Journal of Chemistry 2020, 2020, https://doi.org/10.1155/2020/6735232.

12. Oyebamiji, A.K.; Josiah, O.M.; Akintelu, S.A.; Adeoye, M.D.; Sabitu, B.O.; Latona, D.F.; Esan, A.O.; Soetan, E.A.; Semire, B. Dataset on insightful bio-evaluation of 2-(quinoline-4-yloxy)acetamide analogues as potential anti-Mycobacterium tuberculosis catalase-peroxidase agents via in silico mechanisms. Data in Brief 2021, 38, https://doi.org/10.1016/j.dib.2021.107441.

13. Oyebamiji, A.K.; Fadare, O.A.; Akintelu, S.A.; Semire, B. Biological Studies on Anthra[1,9-cd]pyrazol6(2D)-one Analogues as Anti-vascular Endothelial Growth Factor Via In silico Mechanisms. Chemistry Africa 2021, 4, 955-963, https://doi.org/10.1007/s42250-021-00276-2. 
14. Oyebamiji, A.; Akintelu, S.A.; Mutiu, O.; Adeosun, I.; Kaka, M.; Olotu, T.; Soetan, A.; Adelowo, J.; Semire, B. In-Silico Study on Anti-cancer Activity of Selected Alkaloids from Catharanthus roseus. ResearchGate 2021, 5, 1315-1322.

15. Oyebamiji, A.K.; Akintelu, S.A.; Amao, O.P.; Kaka, M.O.; Morakinyo, A.E.; Amao, F.A.; Semire, B. Dataset on theoretical bio-evaluation of 1,2,4-thiadiazole-1,2,4-triazole analogues against epidermal growth factor receptor kinase down regulating human lung cancer. Data in Brief 2021, 37, https://doi.org/10.1016/j.dib.2021.107234.

16. Akintelu S.A.; Folorunso A.S.; Oyebamiji A.K. Phytochemical and antibacterial investigation of Moringa oleifera seed: experimental and computational approaches. Eclética Química Journal 2021, 46, 17-25, http://dx.doi.org/10.26850/1678-4618eqj.v46.2.2021.p17-25.

17. Oyebamiji, A.K.; Mutiu, O.A.; Amao, F.A.; Oyawoye, O.M.; Oyedepo, T.A.; Adeleke, B.B.; Semire, B. Dataset on in-silico investigation on triazole derivatives via molecular modelling approach: A potential glioblastoma inhibitors. Data in Brief 2021, 34, https://doi.org/10.1016/j.dib.2020.106703.

18. Oyebamiji, A.; Semire, B. In-Silico Study on Anti-bacteria and Anti-fungal Activities of 3,4Dihydropyrimidin-2(1H)-One Urea Derivatives. Chemistry Africa 2020, 4, 149-159, https://doi.org/10.1007/s42250-020-00202-y.

19. Oyebamiji, A.K.; Abdulsalami, I.O.; Semire, B. Dataset on Insilico approaches for 3,4-dihydropyrimidin2(1H)-one urea derivatives as efficient Staphylococcus aureus inhibitor. Data in Brief 2020, 32 , https://doi.org/10.1016/j.dib.2020.106195.

20. Adegoke, R.O.; Oyebamiji, A.K.; Semire, B. Dataset on the DFT-QSAR, and docking approaches for anticancer activities of 1, 2, 3-triazole-pyrimidine derivatives against human esophageal carcinoma (EC-109). Data Brief 2020, 31, https://doi.org/10.1016/j.dib.2020.105963.

21. Oyebamiji, A.; Tolufashe, G.; Semire, B. Inhibition study on Anti-type 3 of $3 \alpha$-Hydroxysteroid Dehydrogenase Activity against 1,2,3-Triazolo[4,5-D]Pyrimidine Derivatives: Molecular modelling Approach. Scientific African 2020, 8, https://doi.org/10.1016/j.sciaf.2020.e00444.

22. Oyewole R.O.; Oyebamiji A.K.; Semire B. Theoretical calculations of molecular descriptors for anticancer activities of 1, 2,3-triazole-pyrimidine derivatives against gastric cancer cell line (MGC-803): DFT, QSAR and docking approaches. Heliyon 2020, 6, https://doi.org/10.1016/j.heliyon.2020.e03926.

23. Oyebamiji, A.K.; Fadare, O.A.; Semire, B. Anti-gastric cancer activity of 1,2,3-triazolo[4,5-d]pyrimidine hybrids (1,2,3-TPH): QSAR and molecular docking approaches. Heliyon 2020, 6, https://doi.org/10.1016/j.heliyon.2020.e03561.

24. Semire, B.; Oyebamiji, A.; Odunola, O. Electronic Properties' Modulation of D-A-A via Fluorination of 2Cyano-2-pyran-4-ylidene-Acetic Acid Acceptor Unit for Efficient DSSCs: DFT-TDDFT Approach. Scientific African 2020, 7, https://doi.org/10.1016/j.sciaf.2020.e00287.

25. Oyebamiji A.K.; Semire, B. In Vitro Biological Estimation of 1,2,3-Triazolo[4,5-d]pyrimidine Derivatives as Anti-breast Cancer Agent: DFT, QSAR and Docking Studies. Current pharmaceutical biotechnology 2020, 21, 70-78, https://doi.org/10.2174/1389201020666190904163003.

26. Oyebamiji, A.K.; Fadare, O.A.; Semire, B. Hybrid-based drug design of 1,2,3-triazole-pyrimidine-hybrid derivatives: Efficient inhibiting agents of mesenchymal-epithelial transition factor reducing gastric cancer cell growth. Journal of Chemical Research 2020, 44, 277-280, https://doi.org/10.1177/1747519819898354.

27. Liao, K.H.; Chen, K.-B.; Lee, W.-Y.; Sun, M.-F.; Lee, C.-C.; Chen, C.Y.-C. Ligand-Based and StructureBased Investigation for Alzheimer's Disease from Traditional Chinese Medicine. Evidence-Based Complementary and Alternative Medicine 2014, 2014, http://dx.doi.org/10.1155/2014/364819.

28. Pandey, A.V.; Bisht, H.; Babbarwal, V.K.; Srivastava, J.; Pandey, K.C.; Chauhan, V.S. Mechanism of malarial haem detoxification inhibition by chloroquine. Biochem $J$ 2001, 355, 333-338, http://dx.doi.org/10.1042/0264-6021:3550333.

29. Mahantheshappa, S.S.; Shivanna, H.; Nayak, D.S. Synthesis, antimicrobial, antioxidant, and ADMET studies of quinoline derivatives. European Journal of Chemistry 2021, 21, 37-44, https://doi.org/10.5155/eurjchem.12.1.37-44.2038. 